\section{Minimalt invasiv obduksjon i fattige land}

I fattige land kan obduksjon basert på prøver fra blod, cerebrospinalvæske og utvalgte organer være en velegnet metode for å stille riktig diagnose post mortem.

Metodene som i dag brukes for å fastslå dødsårsak i middelinntekts- og lavinntektsland er ofte lite pålitelige. En prosedyre basert på anamnese, pasientjournal og komplett diagnostisk obduksjon kan av ulike årsaker være vanskelig å gjennomføre. Kan såkalt minimalt invasiv obduksjon, der man tar blodprøver, prøve av cerebrospinalvæske og biopsier av et utvalg organer hos den avdøde være et godt alternativ?

Ved et sykehus i Mosambik ble det hos 112 avdøde gjort både minimalt invasiv obduksjon og komplett diagnostisk obduksjon. Deretter ble de fastslåtte dødsårsakene ved de to metodene sammenlignet (1). Ved minimalt invasiv obduksjon ble det stilt diagnose hos 100, og 85 av disse fikk samme diagnose som ved komplett obduksjon.

- Dette er overraskende gode resultater, sier Cecilie Alfsen, som er overlege og førsteamanuensis ved Avdeling for patologi, Akershus universitetssykehus. - Jeg hadde trodd at andelen ikke-konklusive obduksjoner ved minimalt invasiv obduksjon skulle være høyere. Den høye validiteten kan ha sammenheng med den store andelen svulster og infeksjoner i denne spesielle populasjonen, mener hun.

- Selv om minimalt invasiv obduksjon skulle vise seg å være en god metode ved utvalgte problemstillinger, vil den ikke kunne bli rutine her, ettersom den er dårlig egnet ved kardiovaskulær sykdom, lungesykdom, demens og annen hjernesykdom, som er vanlige dødsårskader i Norge. Dessuten er den kliniske premortale diagnostikken her i landet så god at man neppe vil få vesentlig tilleggsinformasjon ved minimalt invasiv obduksjon, sier Alfsen.

\section{Petter Morten Pettersen}

Sykehuset Østfold

\section{Litteratur}

1. Castillo P, Martínez MJ, Ussene E et al. Validity of a Minimally Invasive Autopsy for Cause of Death Determination in Adults in Mozambique: An Obser vational Study. PLoS Med 2016; 13: e1002171.

\title{
Tvungen eller frivillig avrusning ved opioidavhengighet?
}

\author{
I Malaysia er tvungen avrusning ved opioidavhengighet vanlig, men \\ effekten er dårlig sammenliknet med frivillig behandling med metadon.
}

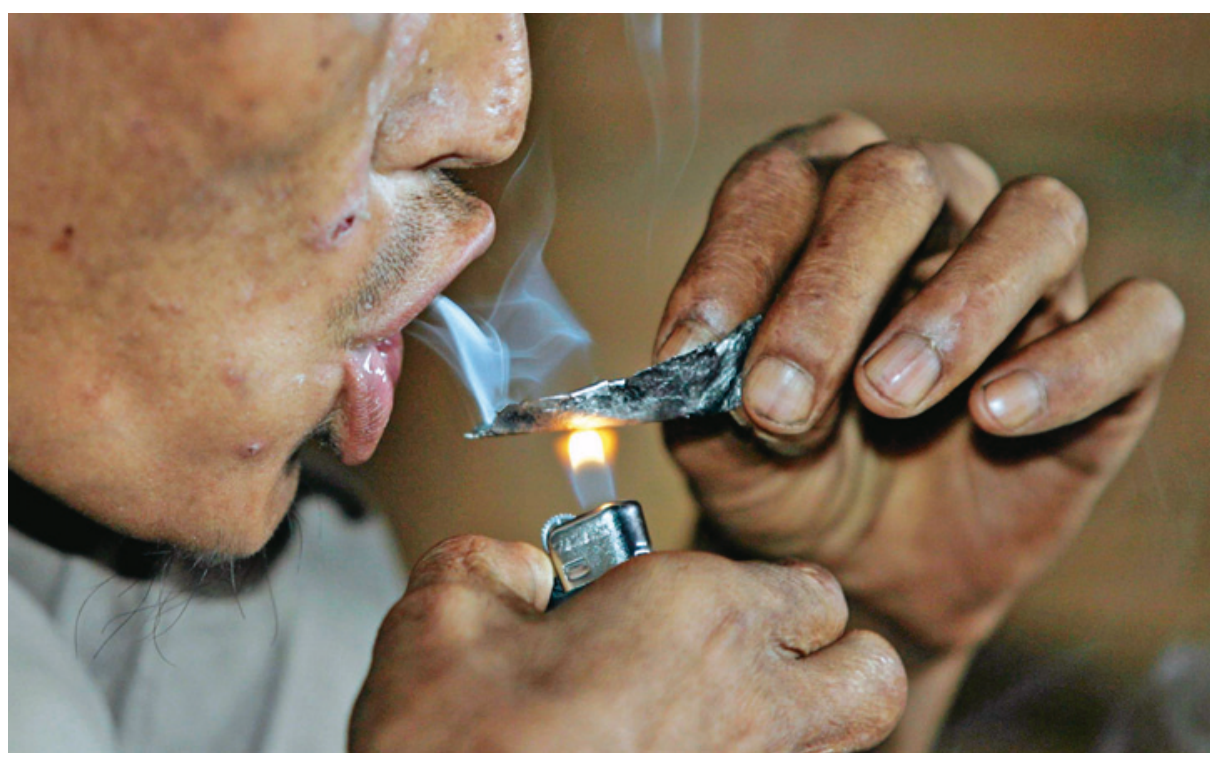

Illustrasjonsfoto: Michael Reynolds/EPA/NTB scanpix

Malaysia er et land med høy forekomst av heroinmisbruk, og i flere tiår har tvangsavrusning i lukkede institusjoner vært utbredt. I en prospektiv, observasjonell studie er effekten av tvungen avrusning sammenlignet med frivillig substitusjonsbehandling med metadon undersøkt (1).

Deltagerne i studien var voksne som oppfylte kriterier for opioidavhengighet og som var bosatt i et bestemt område i Malaysia. 89 personer ble rekruttert fra sentre for tvungen behandling og 95 fra frivillig behandling. Tvangsbehandlingen gikk ut på opphold i lukkede sentre og tvungen deltagelse i arbeidstrening, psykososial terapi og fysisk aktivitet. Den frivillige behandlingen innebar innleggelse og deretter poliklinisk behandling med metadon og tilbud om deltagelse i arbeidstrening, psykososial terapi og fysisk aktivitet.

Pasientene ble fulgt $\mathrm{i}$ opptil 12 måneder etter utskrivning med urinprøver og intervjuer hver tredje måned. Median tid til tilbakefall var 31 dager (95\% KI 26-32) hos dem som ble tvangsbehandlet versus 352 dager hos dem som fikk frivillig substitusjonsbehandling. De som fikk frivillig behandling, hadde $84 \%$ lavere risiko for tilbakefall til misbruk av opiater enn de som ble tvangsbehandlet.

Forfatterne påpeker at motivasjonen for avrusning var lavere hos dem som ble tvangsbehandlet. De konkluderer likevel med at substitusjonsbehandling basert på frivillighet er mye mer effektivt enn tvungen avrusning, og at tvungen avrusning ikke har noen plass i behandling av rusmiddelmisbrukere.

\section{Matilde Risopatron Berg}

Sykehuset Innlandet, Hamar

\section{Litteratur}

1. Wegman MP, Altice FL, Kaur S et al. Relapse to opioid use in opioid-dependent individuals released from compulsory drug detention centres compared with those from voluntary methadone treatment centres in Malaysia: a two-arm, prospective observational study. Lancet Glob Health 2016. E-publisert 7.1.2016 